\title{
GENETIC VARIATION AND EFFECTIVE POPULATION SIZE IN Dipteryx alata PROGENIES IN PEDERNEIRAS, SÃO PAULO, BRAZIL ${ }^{1}$
}

Wanderley dos Santos ${ }^{2}$, Ananda Virginia Aguiar ${ }^{3}$, Danilla Cristina Lemos Souza ${ }^{4}$, Diego Gabriel Torres

Dini $^{2}$, Francine Beatriz de Souza ${ }^{2}$, Cleiton Dalastra ${ }^{2}$, José Arimatéia Rabelo Machado ${ }^{5}$, Valderês Aparecida de Sousa $^{3}$, Mario Luiz Teixeira de Moraes ${ }^{6}$, Miguel Luiz Menezes Freitas ${ }^{7^{*}}$ and Alexandre Magno Sebbenn ${ }^{7}$

\footnotetext{
${ }^{1}$ Received on 10.04.2017 accepted for publication on 20.06.2018.

${ }^{2}$ Universidade Estadual Paulista Júlio de Mesquita Filho, Doutor em Agronomia, São Paulo, SP-Brasil. E-mail: <wanderley.dossantos@hotmail.com>,<dirgo.torres.dini@gmail.com>,<francinnysouza@yahoo.com.br>and<sauems@gmail.com>.

${ }^{3}$ Empresa Brasileira de Pesquisa Agropecuária, Centro Nacional de Pesquisa de Florestas, Colombo, PR-Brasil. E-mail: $<$ ananda@yahoo.com.br $>$ and $<$ valderes.sousa@embrapa.br $>$.

${ }^{4}$ Universidade Estadual Paulista Júlio de Mesquita Filho, Doutor em Ciência Florestal, São Paulo, SP-Brasil. E-mail: $<$ danillacristina@ig.com.br>.

${ }^{5}$ Instituto Florestal do Estado de São Paulo, Divisão de Florestas e Estações Experimentais, Bauru, SP-Brasil. E-mail: $<$ j.rabelomachado@yahoo.com.br>.

${ }^{6}$ Universidade Estadual Paulista Júlio de Mesquita Filho, Departamento de Fitotecnia, Iha Solteira, SP-Brasil. E-mail: $<$ teixeira@agr.feis.unesp.br>

${ }^{7}$ Instituto Florestal do Estado de São Paulo, Secretaria Meio Ambiente do Estado de São Paulo, SP-Brasil. E-mail: <miguellmfreitas@yahoo.com.br>and<alexandresebbenn@yahoo.com.br>.

*Corresponding author.
}

\begin{abstract}
Genetic and phenotypic parameters of fork (BIF), stem form (RET) and diameter at breast height (DBH) for Dipteryx alata provenances and progenies were assessed. The trial was lead in a randomized block design, with 43 treatments (26 and 17 progenies from the municipalities of Três Lagoas and Brasília in the state of Mato Grosso do Sul and Distrito Federal, Brazil, respectively) and five plants per plot. The spacing between plants was $3 \times 3$ meters. The data analysis was performed using the REML/BLUP method (restricted maximum likelihood best linear unbiased prediction). Significant differences were detected between progenies only for DBH. The individual genetic values ranged from 3.7 to $21.7 \%$ for BIF and DBH; genetic variation among progenies ranged from 9 to $10.5 \%$ for $\mathrm{BIF}$ and $\mathrm{DBH}$ among provenances. Individual heritability in the strict sense was high for DBH (minimum from 0.31), revealing the potential for genetic improvement. Provenance and progenies trial showed genetic variability which can be exploited in forest improvement programs with a broad genetic base.
\end{abstract}

Keywords: Tropical trees; Ex situ conservation; Quantitative genetics.

\section{VARIAÇÃO GENÉTICA E TAMANHO EFETIVO POPULACIONAL EM PROGENIES DE DIPTERYX ALATA EM PEDERNEIRAS, SÃO PAULO, BRASIL}

RESUMO - Foram avaliados os parâmetros genéticos e fenotípicos da bifurcação (BIF), forma do fuste (RET) e diâmetro à altura do peito (DAP) para as procedências e progênies de Dipteryx alata. O experimento foi instalado em delineamento em blocos ao acaso, com 43 tratamentos (26 e 17 progênies dos municipios de Três Lagoas e Brasília no Estado de Mato Grosso do Sul e Distrito Federal, respectivamente) e cinco plantas por parcela. O espaçamento entre plantas foi de $3 \times 3$ metros. A análise dos dados foi realizada pelo método REML / BLUP (máxima verossimilhança restrita melhor predição linear não viesada). Foram detectadas diferenças significativas entre progênies apenas para DAP. Os valores genéticos individuais variaram de 3,7 a 21,7\% para BIF e DAP; A variação genética entre as progênies variou de 9 a 10,5\% para BIF 


\begin{abstract}
e DAP entre as procedencias. A herdabilidade individual no sentido restrito foi alta para o DAP (mínimo de 0,31), revelando o potencial de melhoramento genético. As procedências e progênies demonstraram ter variabilidade genética, que pode ser explorada em programas de melhoramento florestal, com ampla base genética.
\end{abstract}

Palavras-Chave: Arvores tropicais, Conservação ex situ, Genética quantitativa.

\section{INTRODUCTION}

Dipteryx alata Vogel, Leguminosae Faboideae (baru), is a valuable forest species for its diversity that includes landscaping, human and animal food, shipbuilding and civil construction (Lorenzi, 1992), paper manufacture for fast printing, gift wrapping paper and packaging paper (Andrade and Carvalho, 1996). This species is part of a native trees group used by the regional population as an additional source of family income through fruit exploitation (Sano et al., 2004). D. alata pulp and seeds are highly energetic, nutritious and rich in minerals, mainly potassium. The seeds have a flavor similar to peanuts. The pulp of the fruits is used for sweets and jellies production (Silva et al., 1994). It is also used in popular medicine as an antirheumatic drug (Brandão, 1993).

From the native species of the Brazilian Savannah (Cerrado), D. alata stands out for its wide distribution and coexistence with the exploitation model used by rural populations, in which plants are preserved in open pasture lands (Corrêas et al., 2000). The maintenance of this species in pasture areas is mainly due to its silvopastoral and ornamental potential. Its crown is dense and wide, with large wind-resistant branches, good for shade, and it's able to integrate different agroforestry systems (Botezelli et al., 2000). It is one of the most promising native fruit trees for cultivation due to its multiple uses, high rate of seed germination and seedlings establishment (Sano et al., 2004).

Natural populations of $D$. alata, as well as those of countless native species, underwent drastic reduction and fragmentation. Currently, individuals of the species are more easily found in pasture areas. One of the main effects from natural populations reduction and fragmentation is the inbreeding onset as a consequence of the potentially reproductive individuals growing apart, gene flow reduction and the increase of genetic divergence among the remaining species populations (Sebbenn et al., 2011). For these reasons, the ex situ germplasm conservation is of vital importance, considering that the agricultural landscape is constantly changing, with a higher probability of germplasm loss in those environments (Kageyama et al., 1998).

For genetic conservation actions to be more effective, it is necessary to characterize the available materials in active germplasm banks (provenance and progeny trials), seeking a deeper knowledge of its genetic potential. Therefore, the next stages of seed and propagule collection for ex situ conservation are directed towards less representative populations in these banks, showing high genetic variability, and mainly towards those populations which are subject to higher risk of extinction. Studies on effective population size and genetic variation are necessary to properly define sampling and conservation strategies to be applied in natural or ex situ populations. Several papers emphasize the importance of quantitative traits to estimate the genetic variability, among which stand out (Guerra et al., 2009; Sebbenn et al., 2009a; Tung et al., 2010; Batista et al., 2012; Moraes et al., 2013; Sant'Ana et al., 2013; Zaruma et al., 2015; Kubota et al., 2015). Knowledge of genetic variability degree both at progeny and provenance levels is an unavoidable preliminary step to establish and consolidate genetic conservation and improvement programs.

The purpose of this work is to estimate the effective population size, as well as the genetic parameters within and between the $D$. alata provenances for the fork, stem form and DBH traits. The hypotheses guiding the fulfillment of purpose follows: (i) verify if the trial has enough genetic variability based on quantitative traits to ensure the viability for conservation and genetic improvement programs; (ii) analyze the most expressive differences between provenances or progenies; (iii) check whether the provenances have an appropriate effective population size to ensure the viability of subsequent selection and improvement cycles.

\section{MATERIALS AND METHODS}

The studied area is located in the Experimental station of Pederneiras, in the State of São Paulo, Brazil (22 $2^{\circ} 9^{\prime} 52.03^{\prime \prime} \mathrm{S}$ and 48 49'13.37" W and 581 maltitude). The typical climate is temperate with warm and rainy

Revista Árvore. 2018;42(3):e420310

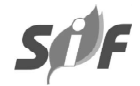


summers and dry winters. The annual temperature is $21.1^{\circ} \mathrm{C}$ and the average annual rainfall is $1,300 \mathrm{~mm}$ (Veiga, 1975). Progenies and provenances test was started in 1986, in a block randomized design, with 43 treatments (seeds of 26 and 17 progenies from Três Lagoas and Brasília in the State of Mato Grosso do Sul and the Distrito Federal, Brazil, respectively), from two to eight replicates by progeny and five plants per plot in a 3 x 3 meters spacing. The trial was evaluated at 27 years old (2013) for survival and fork (BIF), stem form (RET), and diameter at breast height ( $\mathrm{DBH}$, in $\mathrm{cm})$. In order to evaluate BIF and RET, a scale of 1 to 5 was used (Guerra et al., 2009). The classification scale for fork was defined as follows: up to $2.20 \mathrm{~m}-1$. Fork smaller than $1.30 \mathrm{~m}$, with the same diameter from the main stem; 2. Fork greater than $1.30 \mathrm{~m}$ with the same from the main stem; 3 . Fork smaller than $1.30 \mathrm{~m}$ with a smaller diameter than the main stem; 4. Fork greater than $1.30 \mathrm{~m}$ with a smaller diameter than the main stem; 5 . No fork. The classification scale for stem straightness up to 2.20 meters was defined as follows: 1 . Accented tortuosity throughout stem; 2 . Accented tortuosity smaller than $1.30 \mathrm{~m} ; 3$. Accented tortuosity greater than $1.30 \mathrm{~m}$; 4. Mild tortuosity throughout stem; 5. No tortuosity. The descriptions of the notes used for BIF and RET are shown in Sant'ana et al. (2013).

Deviation analysis. The deviation analyses were performed in order to verify significant differences between progenies and provenances for the studied traits. First, a joint analysis (provenances and progenies) was carried out, followed by an individual analysis (progeny). The estimates of variance components and genetic parameters were performed with REML/BLUP (restricted maximum likelihood/best linear unbiased prediction), starting with unbalanced data and using the genetic statistical software SELEGEN-REML/BLUP (Resende, 2002). It was assumed that the progenies were generated by open pollination and are composed by half-brothers.

Estimates of variance components and genetic parameters - The components of the variance and genetic parameters are estimated according to the following:

a)Individual phenotypical variance $\left(\hat{\sigma}_{f}^{2}\right)$ :

$\hat{\sigma}_{f}^{2}=\hat{\sigma}_{a}^{2}+\hat{\sigma}_{c+}^{2} \hat{\sigma}_{e}^{2}$

b) Individual heritability in the strict sense, that is, the mean, from additive effects: $\hat{h}_{a}^{2}=\frac{\hat{\sigma}_{a}^{2}}{\hat{\sigma}_{f}^{2}}$

c) Additive heritability within plot:

$$
\hat{h}_{a d}^{2}=\frac{0,75 \cdot \hat{\sigma}_{a}^{2}}{0,75 \cdot \hat{\sigma}_{a}^{2}+\hat{\sigma}_{e}^{2}}
$$

The coefficient of genetic variation within progenies $\left(\mathrm{CV}_{\mathrm{pg}}\right)$, individual variation $\left(\mathrm{CV}_{\mathrm{gi}}\right)$, experimental variation $\left(\mathrm{CV}_{\mathrm{e}}^{\mathrm{pg}}\right)$, and plot effects determination $\left(\mathrm{c}_{\mathrm{p}}^{2}\right)$ were used in the expression:

d)Coefficient of individual additive genetic variation:Eq4

$C V_{g i}(\%)=\frac{\sqrt{\hat{\sigma}_{a}^{2}}}{\hat{m}} 100(m=$ general character average $)$.

e)Coefficient of genotypic variation among progenies:

$C V_{g p(\%)=} \frac{\sqrt{0,25 . \hat{\sigma}_{a}^{2}}}{\hat{m}} \cdot 100$

f)Coefficient of experimental variation:

$C V_{e(\%)}=\frac{\sqrt{\left[\left(0,75 \cdot \hat{\sigma}_{a}^{2}+\hat{\sigma}_{e}^{2} /\right) n\right]+\hat{\sigma}_{c}^{2}}}{\hat{m}} .100$

g)Coefficient of relative variation:

$$
C V_{r}=\frac{C V_{g p}}{C V_{e}} ;
$$

h)Coefficient of determination from the plot $\operatorname{effects}\left(\mathrm{c}_{\mathrm{p}}^{2}\right)$ :

$$
\hat{C}_{p}^{2}=\frac{\hat{\sigma}_{c}^{2}}{\hat{\sigma}_{f}^{2}}
$$

The effective population size $\left(N_{e}\right)$ was obtained based on Resende (2002). The genetic diversity (D) was estimated following Wei and Lindgren (1996): D $=\mathrm{N}_{\mathrm{ef}} / \mathrm{N}_{\mathrm{fo}}$, in which: $0<\mathrm{D} \leq 1 ; \mathrm{N}_{\mathrm{fo}}=$ original number of progenies; $\mathrm{N}_{\mathrm{ef}}=$ effective number of progenies in the progenies trial and is obtained by:Eq9

$$
N_{e f}=\left(\sum k_{f}\right)^{2} / \sum k_{f}^{2}
$$

\section{RESULTS}

\subsection{Joint analysis}

The provenance from Brasília showed a lower survival rate (54\%), and Três Lagoas reached $73 \%$. At 27 years of age, the survival rate of the provenance

Revista Árvore. 2018;42(3):e420310 
Table 1 - Likelihood ratio test (LRT) between provenances and progenies of $D$. alata for the traits: stem bifurcation (BIF), stem straightness (RET) and diameter at breast height $(\mathrm{DBH})$.

Tabela 1 - Teste da razão de verossimilhança (LRT) entre procedências e progênies de D. alata para os caracteres: bifurcação (BIF), forma do fuste (RET) e diâmetro à altura do peito $(D A P)$.

\begin{tabular}{lccc}
\hline Effects & BIF & RET & DBH \\
\hline Provenance & 0,20 & 0,02 & 0,01 \\
Progeny & 1,19 & 2,65 & $18,0^{* *}$ \\
\hline$* * P<0,01$ chi-squared $\left(x^{2}\right)$ &
\end{tabular}

and progeny test was $66.1 \%$. Likelihood ratio test (LTR) results indicated that there were no significant differences between provenances, just between progenies for the DBH (Table 1).

The coefficient of determination of plot effects varied from 0.01 to 0.12 between traits (table 2 ). The coefficients of individual and interprogene genetic variation were high for BIF, RET and $\mathrm{DBH}$, ranging from 10.6 to $21.1 \%$. The coefficients of genotypic variation between progenies were also high for the observed traits, ranging from 5.3 to $10.5 \%$. The coefficient of determination of populations effects was low (0.01) for all traits. Individual heritability, in the strict sense, was low for BIF and RET (maximum of 0.16) and high for DBH (0.33). The averages for studied traits were 3.29 (BIF), 3.19 (RET) and $16.80 \mathrm{~cm}$ (DBH). The coefficient of determination from the plot effects is considered

Table 2 - Genetic parameters, in joint analysis, for provenances and progenies of D. alata for the traits: fork (BIF), stem form (RET) and diameter at breast height (DBH).

Tabela 2 - Parâmetros genéticos, em análise conjunta, para procedências e progênies de D. alata para os caracteres: bifurcação (BIF), forma do fuste (RET) e diâmetro à altura do peito (DAP).

\begin{tabular}{cccc}
\hline Parameters & BIF (note) & RET (note) & DBH $(\mathrm{cm})$ \\
\hline $\mathrm{h}^{2}{ }^{2}$ & $0,08 \pm 0,05$ & $0,16 \pm 0,08$ & $0,33 \pm 0,12$ \\
$\mathrm{C}^{2}{ }_{\mathrm{c}}$ & 0,07 & 0,12 & 0,01 \\
$\mathrm{C}^{2}$ & 0,01 & 0,01 & 0,01 \\
$\left.\mathrm{CV}_{\mathrm{gi}} \mathrm{p} \%\right)$ & 10,57 & 18,16 & 21,08 \\
$\mathrm{CV}_{\mathrm{gp}}(\%)$ & 5,28 & 9,08 & 10,54 \\
$m$ & 3,29 & 3,19 & 16,80 \\
\hline
\end{tabular}

$\mathrm{h}^{2}{ }_{\mathrm{a}}$ is the individual heritability coefficient in the strict sense; $\mathrm{c}^{2}$ and $\mathrm{c}^{2}$ are the coefficients of determination of the effects of the plot and provenance, respectively; $\mathrm{cv}_{\mathrm{ij}}$ and $\mathrm{cv}_{\mathrm{p}}$ are the coefficients of individual and genotypic additive genetic variation between progenies, respectively; $m$ is the general average of the experiment; \pm is the error.

Revista Árvore. 2018;42(3):e420310

Revista Árvore. 2018;42(3):e420310 low (Resende, 2002).

\subsection{Individual analysis}

Significant differences were observed among progenies for the DBH character for both provenances (Table 3). The provenance from Brasília showed lower average values than those from Três Lagoas for all traits. The provenance presents an average tortuosity. The average for DBH character was $16.53 \mathrm{~cm}$ (Brasília) and $16.98 \mathrm{~cm}$ (Três Lagoas).

The coefficients of individual genetic variation $\left(C V_{g i}\right)$ and among progenies $\left(C V_{g p}\right)$ showed similar results for RET and DBH in both provenances. The most significant difference was observed for BIF, with the CVgi being 3.7\% for Brasília and 12.6\% for Três Lagoas, the $C V_{g p}$ for Brasília was $1.9 \%$ and $6.3 \%$ for Três Lagoas. The coefficient of determination from the plot effects $\left(C_{p}^{2}\right)$ for DBH was 0.04 (Brasília) and 0.01 (Três Lagoas). The $C^{2}$ for the RF was 0.09 (Brasília) and 0.13 (Três Lagoas). The individual heritability in the strict sense $\left(h^{2}\right)$ for DBH was high varying from 0.31 (Brasília) and 0.34 (Três Lagoas).

\subsection{Effective population size and genetic diversity}

The studied provenances showed an effective population size $\left(N_{e}\right)$ from 50 and 75 , and genetic diversity $(D)$ of 0.87 and 0.83 , for Brasília and Três Lagoas, respectively (Table 4 ). The genetic diversity in the first population was higher than the second, despite a smaller number of individuals.

\section{DISCUSSION}

\subsection{Joint analysis}

Survival was low for Brasília's provenance and average for Três Lagoas. The latter provenance is more suitable for reforestation in that study region. The difference in the survival rate of provenances confirms that the collection of seeds in populations close to the plantation region should be prioritized, mainly for the genetic conservation of the species. The low survival rate observed in the provenance from Brasília may be a consequence of the origin population being subject to different soil and climatic conditions when compared to those from the plantation region. Scapim et al. (1995) reported that soil and climatic conditions are determinants for success in the survival of this species. When species are introduced to different sites from the origin of mother 
Table 3 - Estimate of genetic parameters for D. alata provenances, at 27 years of age, for the traits: fork (BIF), stem form (RET) and diameter at breast height (DBH).

Tabela 3 - Estimativa dos parâmetros genéticos para as procedências de D. alata, aos 27 anos de idade, para os caracteres bifurcação (BIF), forma do fuste (RET) e diâmetro à altura do peito (DAP).

\begin{tabular}{|c|c|c|c|c|c|c|}
\hline \multirow[b]{2}{*}{ Parameters } & \multicolumn{3}{|c|}{ Brasília } & \multicolumn{3}{|c|}{ Três Lagoas } \\
\hline & BIF(note) & RET(note) & $\mathrm{DBH}(\mathrm{cm})$ & BIF (note) & RET (note) & DBH $(\mathrm{cm})$ \\
\hline $\mathrm{h}_{\mathrm{a}}^{2}$ & $0,01 \pm 0,03$ & $0,19 \pm 0,15$ & $0,31 \pm 0,19$ & $0,12 \pm 0,09$ & $0,16 \pm 0,10$ & $0,34 \pm 0,15$ \\
\hline$c^{2}{ }_{p}^{2}$ & 0,07 & 0,09 & 0,04 & 0,06 & 0,13 & 0,01 \\
\hline $\mathrm{cv}_{\mathrm{gi}}(\%)$ & 3,7 & 20,2 & 21,6 & 12,6 & 18,3 & 21,1 \\
\hline $\mathrm{cv}_{\mathrm{gp}}(\%)$ & 1,9 & 10,1 & 10,8 & 6,3 & 9,2 & 10,5 \\
\hline$m$ & 3,18 & 3,12 & 16,53 & 3,36 & 3,24 & 16,98 \\
\hline $\operatorname{LTR}\left({ }^{2}\right)$ & 0,00 & 1,66 & $4,44^{*}$ & 1,57 & 1,62 & $14,61^{* *}$ \\
\hline
\end{tabular}

**P<0,01;*P<0,05; $\mathrm{h}^{2}$, are the individual heritability coefficients in the strict sense; $\mathrm{c}^{2}$ is the coefficient of determination of the plot effects; $\mathrm{cv}_{\mathrm{g}}$ and $\mathrm{cv}$ are the coefficients of individual and genotypic additive genetic variation between progenies, respectively; $m$ is the general average of experiment; LRT is the test of likelihood ratio (chi-squared $\left(x^{2}\right) \pm$ is the error.

trees, they need climatic conditions similar to the natural habitat, so they can continue to develop their normal physical and phenological traits. Otherwise, changes resulting from acclimation and evolutionary adaptation will be required.

When there are significant differences among progenies, selective thinning can be applied to obtain genetic gain, as well as in seed orchard composition. In other populations from this species, significant variation between provenances and progenies for the DBH traits was also identified (Zaruma et al., 2015). This trait can be used in selection strategies, mainly in obtaining superior individuals for wood production.

\subsection{Individual analysis}

The significant differences observed between progenies for the DBH considering both provenances

Table 4 - Estimate of effective population size and genetic diversity in provenances and progenies of D. alata.

Tabela 4-Estimativa do tamanho efetivo da população e diversidade genética em procedências e progênies de D. alata.

\begin{tabular}{lcc}
\hline Parameters & Brasília & $\begin{array}{c}\text { Três } \\
\text { Lagoas }\end{array}$ \\
\hline Number of progenies: $\mathrm{N}^{\mathrm{f}}$ & 17 & 26 \\
Number of selected progenies: $\mathrm{N}^{\mathrm{fs}}$ & 17 & 26 \\
Number of selected individuals: $n$ & 258 & 466 \\
Average number of selected individuals: $k^{\mathrm{f}}$ & 15,2 & 17,9 \\
Variance of the number of individuals & 38,77 & 68,24 \\
selected by progeny: & & \\
$\alpha^{2}$ & & \\
Effective size: $\mathrm{N}_{\mathrm{e}}$ & 49,8 & 75,4 \\
Genetic diversity: $\mathrm{D}$ & 0,87 & 0,83 \\
\hline
\end{tabular}

suggest their use in genetic improvement programs and ex situ conservation of this species. D. alata has potential for sawing wood and seeds exploitation. Other tree species provenances have shown similar results, such as Handroanthus vellosoi (Toledo) Mattos, for example, has a medium shape $(>2)$, while a Myracrodruon urundeuva F.F. et M.F. Allemão population from Paulo de Faria, SP shows values < 3 (Freitas et al., 2006; Batista et al., 2012). Zaruma et al. (2015) evaluating D. alata fork obtained 3.39 for the Brasília provenance. However, most progenies from this provenance showed fork lower than $1.30 \mathrm{~m}$ with a smaller diameter compared to the main stem and accentuated tortuosity, higher than 1.30 $\mathrm{m}$. Since this species is applied for multiple uses, an individual with good growth and stem shape could be selected for wood use in systems such as silvopastoral. The silvopastoral production matrix has demands for fast-growing native species, so $D$. alata generates impressive results for the sustainability of this sector (Oliveira Neto et al., 2010).

The coefficients of individual genetic variation and between progenies are important in order to know the attributes of the material for genetic improvement, with those higher than $7 \%$ being considered high (Sebbenn et al., 1998). This indicates that the two provenances of this study have potential for this purpose. In addition to being important from the genetic improvement point of view, these estimates indicate that a considerable part of the genetic variability of the provenance was preserved ex situ for the traits evaluated. (Sebbenn et al., 2009b). Genetic variability of a population constitutes the basic raw material of the improvement (Sebbenn et al., 1994). The selection of individuals and progenies, based on DBH, will 
contribute to the increase of the population average in the wood volume of the following generations.

\subsection{Effective population size and genetic diversity}

The increase in productivity depends on the genetic variation available to obtain continuous genetic gain throughout the reproductive cycle in improvement populations. The recommended minimum acceptable value for maintaining a satisfactory genetic base between selection cycles is between 30 and 60 (Leonardecz Neto et al., 2003). Authors such as Resende (1999) suggest that to maintain genetic variability in selection cycles it is important to maintain an effectivesize $\left(N_{e}\right)$ around 50 , thus minimizing the loss of genetic variability and keeping favorable alleles throughout the selection cycles, ensuring that genetic advances in continuous cycles are not compromised. The $N_{e}$ resulting from the proposed selection suggests that the maintenance of genetic variation can be exploited in the following selection cycles, guaranteeing genetic gain in future selections. The loss of genetic variation in an improvement program affects the maintenance of the genetic aptitude of the populations, reducing the evolutionary potential (Frankham et al., 2004).

However, artificial selection is key in the improvement and this decreases the $N_{e}$ reducing genetic variability and facilitating the increase of endogamy (Frankham et al., 1999). The provenances studied in this work have an effective size greater than the minimum value stipulated for ex situ conservation, which is 50 . Therefore, that minimum value reduces the probability in that population of losing rare and less frequent alleles. An estimate of $N_{e}$ of 50 is adequate to retain the rare alleles whose frequency in the provenance is lower than $6 \%$, with a confidence level of $95 \%$; if that frequency were $1 \%$, the $N_{e}$ would have to be raised to 150 (Vencovsky, 1987; Sebbenn et al., 2003).

\section{CONCLUSIONS}

Genetic control of fork and stem form is low, while for DBH it turned out to be high, thus presenting a significant variation with exploitation potential in genetic improvement.

The provenance from Três Lagoas has a broader genetic base and a higher growth performance than the provenance from Brasília.
The effective population size of the provenances contemplates the recommended values for each cycle of genetic improvement and conservation. Therefore, for this population to be used in genetic conservation programs, the effective population size must be preserved ex situ and be substantially increased.

\section{REFERENCES}

Andrade AM, Carvalho CJ. Produção de celulose e de papel Kraft da madeira de baru (Dipteryx alata Vog.). Floresta e Ambiente. 1996;3(1):28-35.

Batista CM, Freitas MLM, Moraes MA, Zanatto ACS, Santos PC, Zanata M, et al. Estimativas de parâmetros genéticos e a variabilidade em procedências e progênies de Handroanthus vellosoi. Pesquisa Florestal Brasileira. 2012;32(71):269-76.

Botezelli L, Davide AC, Malavasi MM. Características dos frutos e sementes de quatros procedências de Dipteryx alata VOGEL (BARU). Cerne. 2000;6(1):121-7.

Brandão M. plantas medicamentosas de uso popular dos cerrados mineiros. Daphne. 1993;3(4):11-20.

Corrêas GC, Naves RV, Rocha MR, Zica LF. Caracterização física de frutos de baru (Dipteryx alata Vog.) em três populações nos cerrados do Estado de Goiás. Pesquisa Agropecuária Tropical. 2000;30(2):5-11.

Frankham R, Lees K, Montgomer YME, England PR, Edwin H, Lowe EH, et al. Do population size bottlenecks reduce evolutionary potential? Animal Conservation. 1999;2(4):255-60.

Frankham R, Ballou JD, Briscoe DA. A primer of conservation genetics. Cambridge: Cambridge University; 2004.

Freitas ML, Aukar AA, Sebben AM, Moraes MLT, Lemos EGM. Variação genética em progênies de Myracrodruon urundeuva F.F. \& M.F. ALLEMÃO em três sistemas de cultivo. Revista Árvore.2006;30(3):319-29.

Guerra CRSB, Moraes MLT, Silva CLSP, Canuto DSO, Andrade JAC, Freitas MLM ,et al. Estratégias de seleção dentro de progênies em 
duas populações de Myracrodruon urundeuva Fr. All. Scienti Forestalis. 2009;37(81):79-87.

Kageyama PY, Gandara FB, Souza LMI. Consequências genéticas da fragmentação sobre populações de espécies arbóreas. Série Técnica IPEF. 1998;12(32):65-70.

Kubota TYK, Moraes MA, Silva ECB, Pupin S, Aguiar AV, Moraes MLT, et al. Variabilidade genética para caracteres silviculturais em progênies de polinização aberta de Balfourodendron riedelianum (Engler). Scientia Forestalis. 2015;43(106):407-15.

Leonardecz Neto E, Vencovsky R, Sebbenn AM. Ajuste para a competição entre plantas em teste de progênies e procedências de essências florestais. Scientia Forestalis. 2003;(63):136-49.

Lorenzi H. Árvores brasileirasp manual de identificação e cultivo de plantas arbóreas nativas do Brasil. Nova Odessa: Plantarum; 1992.

Moraes MA, Moraes SMB, Silva ECB, Kubota TYK, Silva AM, Resende MDV, Moraes MLT. Variação genética em progênies de Jacaranda cuspidifolia Mart. utilizando o delineamento sistemático tipo "leque". Scientia Forestalis. 2013;41(98):175-83.

Oliveira Neto SN, Reis GG, Reis MGF, Leite HG. Arranjos estruturais do componente arbóreo em sistema agrossilvipastoril e seu manejo por desrama e desbaste. Informe Agropecuário. 2010;31(257):47-58.

Resende MD. Melhoramento de essências florestais. Inp BORÉM, A. Melhoramento de espécies cultivadas. Viçosa, MG: UFV, 1999. p.589-647.

Resende MD. Software Selegen-REML/BLU: Colombo: Embrapa-CNPF; 2002. (Documentos, 77).

Sano SM, Ribeiro JF, Brito MA. Barup biologia e uso. Planaltina: Embrapa Cerrados; 2004. (Documentos, 116).

Sant'ana Z, Freitas MLM, Moraes MLT, Zanata M, Zanatto ACS, Moraes MA, Sebbenn AM. parâmetros genéticos em progênies de polinização aberta de Enterolobium contortisiliquum (Vell.) Morong em Luiz Antonio, Sp, Brasil. Hoehnea. 2013;40(3):515-20.
Scapim CA, Carvalho CGP, Cruz CD. Uma proposta de classificação dos coeficientes de variação para a cultura do milho. Pesquisa Agropecuária Brasileira. 1995;30:683-6.

Sebbenn AM, Carvalho ACM, Freitas MLM, Moraes SMB, Gaino APSC, Silva JM, et al. Low level of realized seed and pollen gene flow and strong spatial genetic structure in a small, isolated and fragmented population of the tropical tree Copaifera langsdorffii Desf. Heredity. 2011;106(1):134-45.

Sebbenn AM, Freitas MLM, Zanatto ACS, Moraes E. Seleção dentro de progênies de polinização aberta de Cariniana legalis Mart. O. Ktze (Lecythidaceae), visando à produção de sementes para recuperação ambiental. Revista do Instituto Florestal. 2009b;21(1):27-37.

Sebbenn AM, Freitas MLM, Zanatto MCS, Morais E, Moraes MA. Comportamento da variação genética entre e dentro de procedências e progênies de Gallesia integrifolia Vell. Moq. para caracteres quantitativos. Revista do Instituto Florestal. 2009a;21(2):151-63.

Sebbenn AM, Kageyama PY, Vencosvky R. Variabilidade genética, sistema reprodutivo e estrutura genética espacial em Genipa americana L. através de marcadores isoenzimáticos. Scientia Forestalis.1998;53:15-30.

Sebbenn AM, Kageyama PY, Vencovsky R. Conservação genética in situ e numero de matrizes para a coleta de sementes em população de Genipa americana L. Scientia Forestalis. 2003(63):13-22.

Sebbenn AM, Pires CLS, Custódio Filho A, Rosa PRF. Variação genética em progênies de meiosirmãos de pinus caribaea Mor.var. bahamensis Bar.et Gol. na região de Bebedouro, São Paulo. Revista do Instituto Florestal. 1994;6:63-73.

Silva JA, Silva DJ, Junqueira NTV, Andrade LRM. Frutas nativas dos cerrados. Brasília, DF: Embrapa-CpAC/SPI; 1994.

Tung ESC, Freitas MLM, Florsheim SMB, Lima IL, Longui EL, Santos FW, et al. Variação genética para caracteres silviculturais e 
anatômicos da madeira em progênies de Myracrodruon urundeuva (Engler) Fr. Allem. Scientia Forestalis. 2010;38(87):499-508.

Veiga AA. Balanços hídricos das dependências da Divisão de Florestas e Estações Experimentais. São Paulo: Instituto Florestal; 1975.

Vencovsky R. Tamanho efetivo populacional na coleta e preservação de germoplasma de espécies alógomas. Instituto de pesquisa e Estudos
Florestais. 1987;35:79-84.

Zaruma DUG, Canuto DSO, Pupin S, Cambuim J, Silva AM, Mori ES, et al. Variabilidade genética em procedências e progênies de Dipteryx alata vogel para fins de conservação genética e produção de sementes. Scientia Forestalis. 2015;43(107):609-15.

Wei RP, Lindgren D. Effective family number following selection with restrictions.

Biometrics.1996;52:198-208.

Revista Árvore. 2018;42(3):e420310 